\title{
Pengaruh Safety Climate dan Perceived Supervisor Safety terhadap Safety Performance yang Dimediasi oleh Psychological Strain: Studi pada PT PAL Indonesia (Persero)
}

\author{
Dito Vidya Riadianto \\ Ahmad Rizki Sridadi \\ Manajemen, Universitas Airlangga, Indonesia \\ Korespondensi penulis: ditovr30@gmail.com
}

\begin{abstract}
The role of human research is basic to determine the objective of an organization or company. The case of a work accident can be detrimental for workers and can decrease the safety performance of the company. Some factors could affect it for instance human factors (unsafe actions), which are caused by undiscipline in applying regulation of work, worker's skilled less in mastering production tools, etc. While environmental factors can be caused by various things for instance an unsafe circumstance of work which concerns all equipment or machinery, and also buildings. The purpose of this research is to obtain the knowledge to gain broader knowledge about the influence of Safety Climate, Perceived Supervisor Safety, and Psychological Strain on Safety Performance. The research population is about 115 employees consist of 45 supervisors and 70 active employees in the Commercial Ship Division of PT PAL Indonesia (Persero), Surabaya. Due to a total population of 115 employees which consist of 45 supervisors, and 70 active employees are used as respondents to the commercial ship division. The data analysis in this research uses partial least square (PLS). The result obtained from this research is that safety climate and perceived supervisor safety are low practice, so the company's safety performance will be low as well and for the psychological strain highly level could make a negative impact on the company's safety performance.
\end{abstract}

Keywords: Perceived supervisor safety; Psychological strain; Safety climate; Safety performance.

Abstrak. Peran sumber daya manusia merupakan modal dasar dalam penentuan tujuan organisasi atau perusahaan. Kasus kecelakaan kerja dapat merugikan pekerja dan menurunkan kinerja keselamatan pada perusahaan. Beberapa faktor dapat mempengaruhinya, seperti faktor manusia (tindakan tidak aman) yang disebabkan oleh ketidakdisiplinan menerapkan peraturan kerja, pekerja kurang trampil dalam menguasai alat-alat produksi, dan sebagainya. Di sisi lain, faktor lingkungan dapat mengakibatkan berbagai kondisi, antara lain keadaan lingkungan kerja yang tidak aman bagi pekerja menyangkut peralatan atau mesin-mesin dan bangunan atau gedung yang ditempati. Tujuan penelitian ini adalah mengetahui pengaruh Safety Climate, Perceived Supervisor Safety, dan Psy- 
chological Strain terhadap Safety Performance. Populasi penelitan ini berjumlah 115 karyawan yang terdiri atas 45 supervisor dan 70 karyawan aktif pada Divisi Kapal Niaga PT PAL Indonesia (Persero). Jumlah populasi total sebanyak 115 orang karyawan tersebut dijadikan sebagai responden dalam penelitian ini. Analisis data yang digunakan dalam penelitian ini adalah partial least square (PLS). Hasil yang diperoleh dari penelitian ini menunjukkan bahwa apabila safety climate dan perceived supervisor safety pada tingkat yang rendah, maka safety performance perusahaan akan rendah pula, sedangkan tingkat psychological strain yang tinggi dapat berdampak negatif pada safety performance perusahaan tersebut.

Kata kunci: Perceived supervisor safety; Psychological strain; Safety climate; Safety performance.

\section{Article Info:}

Received: October 6, $2020 \quad$ Accepted: September 3, $2021 \quad$ Available online: September 14, 2021 DOI: http://dx.doi.org/10.30588/jmp.v11i1.746

\section{LATAR BELAKANG}

Era saat ini, sumber daya manusia (SDM) masih memegang peran penting bagi keberhasilan organisasi atau perusahaan, karena manusia merupakan aset hidup yang perlu diperhatikan secara khusus oleh perusahaan. Kenyataan bahwa manusia menjadi aset utama bagi organisasi atau perusahaan, maka SDM seharusnya mendapatkan perhatian serius dan dikelola sebaik mungkin. Peran SDM merupakan modal dasar dalam penentuan tujuan organisasi atau perusahaan. Tanpa peran SDM, kegiatan dalam organisasi atau perusahaan tidak akan berjalan dengan baik. Manusia selalu berperan aktif dan dominan dalam setiap kegiatan organisasi, karena mereka menjadi perencana, pela$\mathrm{ku}$, dan penentu terwujudnya tujuan organisasi (Hasibuan \& Lubis, 2018). Salah satu upaya perusahaan untuk mengoptimalkan kontribusi SDM adalah menjamin keselamatan dan kesehatan kerja mereka dalam bekerja.

Pemberian program jaminan keselamatan dan kesehatan kerja masih perlu dilakukan mengingat tingkat kecelakaan kerja di Indonesia masih cukup tinggi. Dalam kasus yang ditemui selama ini, kecelakaan kerja yang terjadi banyak diakibatkan oleh kondisi tidak aman, yakni 71.525 kasus $(58,15 \%)$ dari total kasus selama tahun 2017 (ISafetyMagazine, 2017). Selain faktor kondisi yang tidak aman, kecelakaan kerja juga sering terjadi akibat kesalahan pekerja atau tindakan pekerja yang tidak aman. Kecelakaan kerja akibat tindakan tenaga kerja yang tidak aman mencapai 40.098 kasus $(32,06 \%)$ dari total kasus selama tahun 2017. Untuk mengurangi terjadinya kecelakaan kerja, perusahaan perlu memiliki safety climate atau iklim keselamatan kerja (Dessler, 2015). Dessler (2015) menyimpulkan bahwa komitmen terhadap keselamatan kerja dimulai dari manajemen puncak (top management).

Safety climate merupakan persepsi masing-masing karyawan yang berkaitan dengan aspek-aspek keselamatan dan keamanan kerja (Singer, Lin, Falwell, Gaba, \& Baker, 2009). Memperhatikan hal-hal tersebut, penelitian ini bermaksud untuk membuktikan kebenaran teori terkait pengaruh perceived supervisor safety dan safety climate terhadap safety performance. Pengaruh kedua faktor tersebut dapat menentukan produktivitas perusahaan dalam mencapai tujuannya, sehingga pengaruh faktor-faktor tersebut 
penting untuk dikaji lebih lanjut. Penelitian ini fokus mengkaji kondisi terkait pada perusahaan Badan Usaha Milik Negara (BUMN), yaitu PT PAL Indonesia (Persero). PT PAL Indonesia (Persero) merupakan sebuah BUMN yang bergerak pada bidang galangan kapal, khususnya perbaikan, pemeliharaan, dan pembuatan kapal di atas dan bawah permukaan. Divisi Kapal Niaga merupakan salah satu divisi yang ada di PT PAL Indonesia (Persero) yang memiliki tugas untuk memproduksi kapal-kapal niaga, baik pesanan dari luar maupun dalam negeri. Target kerja pada divisi ini adalah one day, one block. Hal itu membuat para pekerja merasa dituntut atau diberikan beban kerja yang cukup tinggi dengan risiko bahaya atas pekerjaan yang tinggi pula. Salah satu pekerjaan pada Divisi Kapal Niaga yang memiliki risiko bahaya tinggi adalah penggerindaan, baik yang dilakukan oleh pekerja organik, pekerja dengan Perjanjian Kerja Waktu Tertentu (PKWT), maupun sub-kontraktor (Man Power Loading Project).

Tabel 1. Data Safety Performance PT PAL Indonesia (Persero) Tahun 2016-2018

\begin{tabular}{|c|c|c|}
\hline Tahun & Jumlah Kejadian & Keterangan \\
\hline 2016 & 17 & $\begin{array}{l}76,4 \% \text { disebabkan oleh unsafe action } \\
23,6 \% \text { disebabkan oleh unsafe condition }\end{array}$ \\
\hline 2017 & 14 & $\begin{array}{l}71,4 \% \text { disebabkan oleh unsafe action } \\
28,6 \% \text { disebabkan oleh unsafe condition }\end{array}$ \\
\hline 2018 & 10 & $\begin{array}{l}70 \% \text { disebabkan oleh unsafe action } \\
30 \% \text { disebabkan oleh unsafe condition }\end{array}$ \\
\hline
\end{tabular}

Sumber: PT PAL Indonesia (Persero) (2020).

Tabel 1 menunjukkan bahwa jumlah unsafe action pada Divisi Kapal Niaga di PT PAL Indonesia (Persero) masih didominasi perilaku karyawan yang masih tidak sadar akan keselamatan kerja (unsafe action), sedangkan faktor terbanyak kedua pelanggaran keselamatan kerja di perusahaan tersebut disebabkan adanya unsafe condition. Keberhasilan perusahaan menekan angka kecelakaan kerja dan menciptakan lingkungan kerja yang nyaman dan efisien mendorong produktivitas kerja, karena perusahaan memiliki manajemen keselamatan kerja yang cukup baik. Namun, hal itu saja belum dianggap cukup, karena perusahaan juga membutuhkan penerapan tindakan safety yang dilakukan karyawan terhadap program yang telah diberlakukan dan diterapkan di dalam perusahaan. Sesuai penjelasan tersebut, maka penelitian ini bertujuan untuk menguji peran mediasi psychological strain pada pengaruh safety climate dan perceived supervisor safety terhadap safety performance.

\section{KAJIAN TEORITIS}

\section{Safety Climate}

Safety climate dijelaskan oleh Flin, Mearns, O'Connor, dan Bryden (2000) sebagai sebuah gambaran pekerja mengenai keadaan iklim kesehatan dan keselamatan kerja yang merupakan indikator budaya keselamatan kerja pada suatu kelompok atau organisasi. Persepsi karyawan terutama terkait dengan usaha keselamatan selama bekerja juga dijelaskan oleh Cooper dan Phillips (2004) yang menjabarkan bahwa safety climate sebagai suatu gambaran yang dirasakan atau terkait dengan persepsi pekerja akan pentingnya keselamatan dan bagaimana hal tersebut bisa ditetapkan dalam organisasi, sedangkan Glendon dan Litherland (2001) mengemukakan bahwa safety climate terdiri 
atas enam faktor, yaitu (1) Communication and support yakni komunikasi yang baik dan sikap saling mendukung dalam hal safety akan dapat mendorong safety climate dari para karyawan; (2) Adequacy of procedure yakni prosedur yang jelas dan cukup dimengerti oleh karyawan akan membuat mereka merasa nyaman dalam bekerja, sehingga pandangan mereka terhadap pekerjaannya cenderung positif; (3) Work pressure yakni tekanan kerja yang merupakan beban kerja perusahaan pada karyawannya, sehingga tekanan yang terlalu besar dapat membuat mereka kelelahan, sedangkan jika tekanan terlalu kecil akan membuat mereka terlalu lengah dalam bekerja; (4) Personal protective equipment yakni pemakaian APD (Alat Pelindung Diri), sehingga karyawan akan merasa aman dan nyaman dalam bekerja, sedangkan APD disediakan oleh perusahaan untuk kebutuhan karyawannya; (5) Relationship yakni hubungan antarkaryawan dengan rekan kerjanya dan juga hubungan dengan atasan atau bawahannya, sehingga relasi yang baik akan membuat karyawan merasa terlindungi oleh rekan-rekannya ketika mereka bekerja; dan (6) Safety rules yakni aturan tentang keamanan yang tercantum dalam perjanjian kerja antara perusahaan dengan karyawan, sehingga mereka dapat memahami batasan-batasan keselamatan ketika bekerja.

\section{Perceived Supervisor Safety}

Dov (2008) menyatakan bahwa organisasi memiliki banyak tujuan dan cara untuk mencapainya, sehingga atasan perlu membangun kebijakan dan prosedur khusus yang harus diikuti pekerja guna menghasilkan berbagai iklim secara spesifik. Oleh karena itu, safety climate berhubungan dengan persepsi mengenai kebijakan, prosedur, dan praktik berdasarkan perceived supervisor safety. Hal ini sesuai dengan definisi safety climate menurut Neal, Griffin, dan Hart (2000), yaitu persepsi atas kebijakan, prosedur, dan perceive supervisor safety yang terkait dengan keselamatan kerja. Manajer dan supervisor bertanggung jawab untuk mengkomunikasikan prioritas masalah keselamatan dalam organisasi dan membuat keputusan untuk melindungi karyawan (Dov, 2008). Komitmen manajemen terhadap keselamatan menghasilkan keamanan dan peran yang lebih jelas (Hofmann, Morgeson, \& Gerras, 2003). Perceived supervisor safety merupakan komponen di dalam komitmen manajemen terhadap keselamatan dan mencerminkan pelaksanaan kebijakan organisasi dan prosedur di setiap unit kerja (Hofmann et al., 2003).

\section{Psychological Strain}

Organisasi perlu melakukan usaha-usaha untuk mengembangkan potensi dan kompetensi karyawan. Motivator merupakan faktor yang berhubungan dengan pekerjaan yang dilakukan. Motivator adalah faktor yang efektif untuk memotivasi peningkatan kinerja dan secara positif berpengaruh pada kepuasan kerja. Faktor-faktor tersebut adalah prestasi, pengakuan, pekerjaan atau tugas, tanggung jawab, kemajuan, dan kemungkinan bertumbuh (Hersey, Blanchard, \& Dewey, 2008). Pada umumnya, kepuasan kerja dipengaruhi oleh beberapa faktor, di antaranya adalah stres kerja dan ketegangan psikologis (psychological strain). Sehubungan dengan ini, Robbins (2001) mengemukakan bahwa rekan kerja yang mendukung, keserasian pribadi dengan pekerjaan dan peluang yang didapat dari pekerjaan menjadi faktor-faktor kepuasan kerja karyawan. Mereka juga mengatakan bahwa tipe-tipe tingkah laku ini berkaitan dengan kepuasan kerja di kalangan karyawan yang bekerja di sektor formal. Kepuasan kerja juga dapat dikaitkan dengan pengaruh psikologis yang dirasakan jika stres kerja muncul. Artinya, apabila stres kerja meningkat dan diikuti dengan perasaan tegang, maka kepuasan kerja akan menurun (Sell, Brief, \& Schuler, 1981). 


\section{Safety Performance}

Skeepers dan Mbohwa (2015) mendefinisikan safety performance sebagai kualitas pekerjaan yang berkaitan dengan keselamatan meliputi keselamatan organisasi dan manajemen, peralatan keselamatan, angka statistik kecelakaan kerja, pelatihan keselamatan, evaluasinya, dan investigasi kecelakaan kerja. Neal et al. (2000) mendefinisikan safety performance sebagai perilaku kerja relevan berkaitan dengan keselamatan. Safety performance merupakan pernyataan karyawan tentang perilaku kerja yang relevan dengan keselamatan atau kepatuhan untuk menjelaskan aktivitas yang berkaitan dengan keselamatan oleh individu untuk memelihara keselamatan di tempat kerja (Sultana, Andersen, \& Haugen, 2019). Aktivitas keselamatan meliputi perilaku untuk mematuhi standar prosedur kerja dan menggunakan peralatan keselamatan di lingkungan kerja. Safety compliance diukur atas dasar dua hal yang meliputi penggunaan peralatan keselamatan sesuai kebutuhan setiap melakukan pekerjaan dan prosedur keselamatan yang tepat dalam setiap pekerjaan (Hagan, Montgomery, \& O'Reilly (2001). Di sisi lain, safety participation diukur berdasarkan tiga hal meliputi upaya membantu rekan kerja yang sedang bekerja dalam kondisi bahaya, kesediaan melaksanakan kegiatan untuk meningkatkan keselamatan kerja, dan keterlibatan dalam kegiatan keselamatan untuk meningkatkan keselamatan kerja di dalam perusahaan (Neal et al., 2000).

\section{Model Penelitian}

Gambar 1 menunjukkan model penelitian ini yang menggambarkan hubungan antarvariabel dalam penelitian ini yang terdiri atas safety climate dan perceived supervisor safety terhadap safety performance yang dimediasi oleh psychological strain.

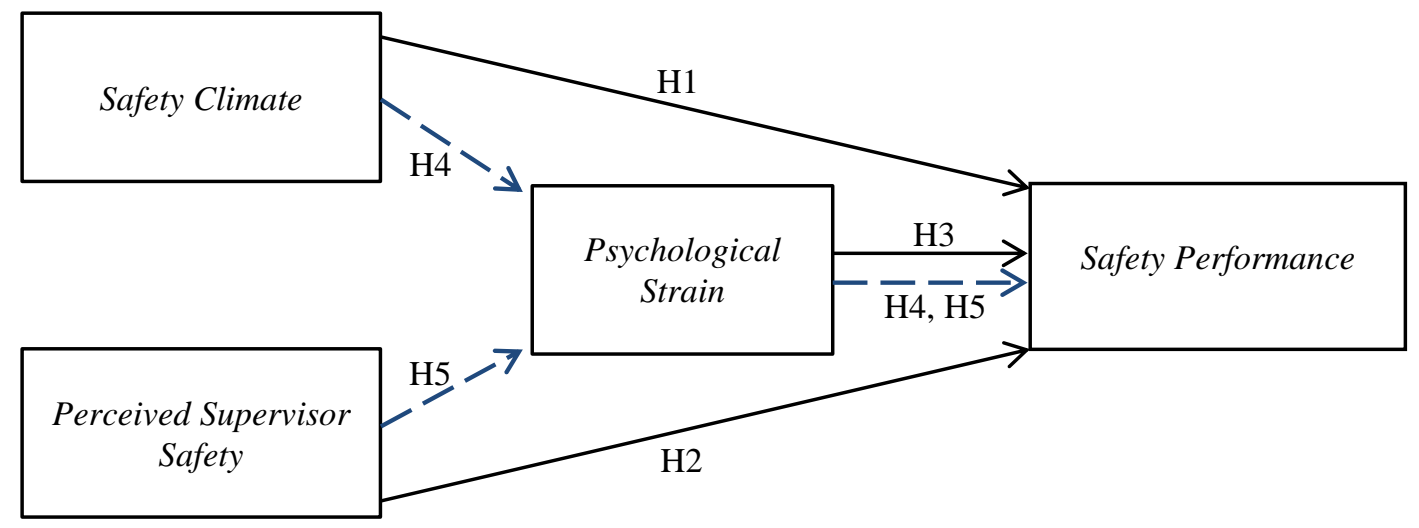

Keterangan:

$\begin{aligned} \longrightarrow & =\text { pengaruh langsung }(\mathrm{H} 1, \mathrm{H} 2, \mathrm{H} 3) \\ ------\rightarrow & =\text { pengaruh tidak langsung atau melalui variabel mediasi }(\mathrm{H} 4, \mathrm{H} 5) .\end{aligned}$

\section{Gambar 1. Model Penelitian}

\section{Pengembangan Hipotesis}

\section{Pengaruh safety climate terhadap psychological strain}

Neal et al. (2000) menjabarkan bahwa safety climate adalah salah satu kondisi atau iklim yang dapat dirasakan oleh individu dalam lingkungan kerjanya, yaitu para 
pekerja yang membangun struktur pemikiran pada lingkungan kerjanya ke dalam pikiran pribadi mereka tentang nilai-nilai yang ada untuk kesejahteraan mereka sendiri. Menurut Hofmann et al. (2003), organisasi memiliki banyak tujuan dan cara untuk menca-pai tujuan tersebut, sehingga manajer perlu membangun kebijakan dan prosedur khusus yang harus diikuti para pekerja dan mampu menghasilkan berbagai iklim khusus serta kepuasan kerja. Hal ini didukung penelitian Stacciarini (2004) yang menyatakan bahwa ketegangan psikologis juga ikut memberi pengaruh secara parsial terhadap kepuasan kerja pada setiap individu. Apabila kepuasan individu terwujud, maka safety climate akan terbentuk pada perusahaan tersebut. Dari uraian tersebut, hipotesis kesatu (H1) dirumuskan sebagai berikut:

H1: Safety Climate berpengaruh signifikan terhadap Psychological Strain.

\section{Pengaruh perceived supervisor safety terhadap psychological strain}

Perceived supervisor safety merupakan komponen di dalam komitmen manajemen terhadap keselamatan kerja dan mencerminkan pelaksanaan kebijakan organisasi dan prosedur di setiap unit kerja (Zohar, 2000). Peran manajer dan supervisor dalam safety performance didokumentasikan dengan baik dalam penelitian safety climate (Clarke, 2006). Hal ini didukung pula oleh penelitian Daud, Yaakob, dan Ghazali (2015) yang menyatakan bahwa teori stres dan peran menyatakan bahwa organisasi menciptakan permintaan dan harapan di dalam pelaksanaan peran yang pada akhirnya akan mentransfer sebagai tekanan peran kepada individu dan tekanan berkelanjutan yang dapat menciptakan masalah kesehatan (Kahn, Wolfe, Quinn, Snoek, \& Rosenthal, 1964), yaitu peran pemahaman pemimpin sangat penting untuk menjaga kondisi kerja yang baik. Dari uraian tersebut, hipotesis kedua $(\mathrm{H} 2)$ dirumuskan sebagai berikut:

H2: Perceived Supervisor Safety berpengaruh signifikan terhadap Psychological Strain.

\section{Pengaruh psychological strain terhadap safety performance}

Ketegangan pekerjaan terkait dengan keselamatan karyawan (Hofmann \& Stetzer, 1996). Menurut Spector dan Jex (1998) serta Spector dan O'Connell (1994), jenis pekerjaan adalah reaksi negatif yang harus dihadapi karyawan terhadap stressor pekerjaan, sedangkan salah satu stressor tersebut adalah ketegangan psikologis (Jex, 1998). Strain psikologis adalah reaksi afektif termasuk sikap (ketidakpuasan kerja) atau emosi (kecemasan atau frustrasi). Hofmann dan Stetzer (1996) menyimpulkan bahwa persepsi kelebihan peran yang tinggi (indikasi tekanan kerja yang dirasakan) dikaitkan dengan kecenderungan meningkat untuk terlibat dalam tindakan yang tidak aman. Alasan utamanya adalah pekerja yang merasakan tekanan kinerja tingkat tinggi memusatkan perhatian mereka pada penyelesaian pekerjaan dan lebih sedikit pada keselamatan prosedur kerja mereka. Hal ini didukung oleh penelitian Siu, Phillips, dan Leung (2004) yang menyatakan bahwa kepatuhan keselamatan dapat diprediksi oleh pengaruh, kecemasan, dan depresi. Dari uraian tersebut, hipotesis ketiga (H3) dirumuskan sebagai berikut:

H3: Psychological Strain berpengaruh signifikan terhadap Safety Performance. 


\section{Peran mediasi psychological strain terhadap safety climate dan safety perfor- mance}

Menurut Wilson, Dejoy, Vandenberg, Richardson, dan McGrath (2004), faktorfaktor penentu safety climate di tempat kerja meliputi: (1) Environmental condition, yaitu kondisi lingkungan kerja menjadi faktor pertama yang dapat mempengaruhi safety climate. Hal tersebut merupakan sesuatu yang wajar, karena lingkungan kerja menjadi pandangan pertama pekerja tentang apa yang mereka kerjakan di dalam lingkungan tersebut; (2) Safety policies and programs, yaitu faktor yang dikelola oleh perusahaan agar kebijakan-kebijakan tersebut menguntungkan dalam arti membuat karyawan dapat bekerja secara aman di lingkungan perusahaan. Kebijakan tersebut biasanya terwujud melalui poster-poster yang ditempel di dinding perusahaan, peraturan kerja yang disepakati, dan adanya tanggung jawab perusahaan terhadap karyawan yang mengalami kecelakaan kerja; (3) Organizational climate, yaitu iklim organisasi yang mencakup sejumlah penilaian individu-individu berbeda di lingkungan kerja. Penilaian ini merupakan penilaian kognitif tentang karakteristik tempat kerja, misalnya kepemimpinan, komunikasi, partisipasi, dan inovasi. Pemahaman ini didukung oleh penelitian Siu et al. (2004) yang menyatakan adanya keterkaitan antara safety climate dan safety performance yang dapat dilihat pada perilaku seseorang yang melakukan tindakan keselamatan. Dari uraian tersebut, maka hipotesis keempat (H4) dirumuskan sebagai berikut:

H4: Psychological Strain memediasi pengaruh Safety Climate terhadap Safety Performance.

\section{Peran mediasi psychological strain terhadap perceived supervisor safety dan safe- ty performance}

Perceived supervisor safety merupakan komponen di dalam komitmen manajemen terhadap keselamatan dan mencerminkan pelaksanaan kebijakan organisasi dan prosedur di setiap unit kerja (Zohar, 2000). Perilaku kepemimpinan penting bagi safety performance yang baik melalui kesadaran karyawan tentang program kegiatan keselamatan organisasi. Kepemimpinan organisasi dapat membantu para pengikut untuk mencapai visi, misi, dan sasaran organisasi. Di sisi lain, hal itu memberikan safety performance yang optimal dan berbeda dari budaya keselamatan. Perilaku kepemimpinan adalah variabel penting untuk mempengaruhi safety performance. Seperti yang dibahas oleh Xu, Lian, Wu, Wang, Fu, dan Xu (2008) serta Lu dan Yang (2011) yang menyatakan bahwa perilaku kepemimpinan dan budaya keselamatan, keduanya merupakan faktor penting untuk mempengaruhi safety performance. Kedua variabel tersebut tidak dapat diabaikan apabila organisasi ingin meningkatkan safety performance. Faktor-faktor perilaku kepemimpinan telah diuji dalam studi sebelumnya dan menemukan bahwa berbagai industri, seperti industri lalu lintas udara, industri tenaga nuklir, dan industri manufaktur, tetapi sangat sedikit penelitian menganalisis perilaku kepemimpinan yang dikombinasikan dengan safety performance. Hal ini didukung oleh penelitian Khdair, Shamsudin, dan Subramanim (2011) yang menyatakan bahwa hubungan antara pemimpin dan safety performance sangat penting dalam perusahaan yang dapat mempengaruhi performa perusahaan tersebut.

H5: Psychological Strain memediasi pengaruh Perceived Supervisor Safety terhadap Safety Performance. 


\section{METODE PENELITIAN}

Sesuai dengan tujuan penelitian ini untuk menganalisis pengaruh pada hipotesis yang telah diajukan, maka penelitian ini menggunakan pendekatan kuantitatif, yaitu penelitian yang menekankan pada pengujian hipotesis, penggunaan data yang terukur, dan pengujian kualitas, sehingga hasil analisis dapat menghasilkan sebuah kesimpulan yang dapat digeneralisasi (Ghozali, 2011). Penelitian ini menggunakan obyek penelitian pada Divisi Kapal Niaga yang ada di sebuah BUMN, yaitu PT PAL Indonesia (Persero) di Surabaya. Penelitian ini menggunakan alat uji statistik untuk menguji hipotesis yang telah diajukan berdasarkan kajian teori dan penelitian sebelumnya. Secara khusus, penelitian ini menggunakan partial least square (PLS) untuk melakukan pengolahan dan analisis data.

Populasi dalam penelitan ini adalah 115 karyawan yang terdiri atas 45 supervisor dan 70 karyawan aktif pada Divisi Kapal Niaga PT PAL Indonesia (Persero). Populasi merupakan wilayah generalisasi yang terdiri atas obyek atau subyek yang mempunyai kualitas dan karakteristik tertentu sesuai yang ditetapkan oleh peneliti untuk dipelajari dan ditarik kesimpulan (Sugiyono, 2017). Menurut Arikunto (2002), apabila subyeknya kurang dari 100 unit, maka penentuan jumlah sampel lebih baik mengambil semua unit tersebut, sehingga penelitiannya merupakan penelitian populasi atau sensus. Namun, jika jumlah subyek cukup besar atau lebih dari seratus unit, maka suatu penelitian dapat menggunakan antara 10\%-15\% atau 15\%-25\% atau lebih (Ghozali, 2011). Jumlah populasi total pada penelitian ini adalah 115 orang karyawan yang terdiri atas 45 supervisor dan 70 karyawan aktif, maka jumlah tersebut secara keseluruhan digunakan sebagai sampel. Dengan kata lain, penelitian ini menggunakan seluruh populasi (sampel jenuh) atau sensus.

Jenis data yang digunakan pada penelitian ini adalah data kuantitatif, yaitu data yang diperoleh dari jawaban kuesioner yang diajukan. Sugiyono (2017) menyatakan bahwa data kuantitatif merupakan data yang berbentuk angka-angka atau data kualitatif yang diangkakan. Sumber data yang digunakan dalam penelitian ini meliputi sumber data primer dan sekunder. Sumber data primer adalah sumber data yang langsung memberikan data kepada peneliti. Sumber data primer dalam penelitian ini adalah responden yang ditentukan melalui penentuan sampel. Sumber data sekunder adalah sumber data yang tidak secara langsung memberikan data kepada peneliti, misalnya melalui orang lain atau dokumen. Pada umumnya, jenis data sekunder meliputi bukti, catatan, atau laporan historis yang telah tersusun dalam bentuk arsip (data dokumenter) yang dipublikasikan dan diperoleh secara acak melalui media perantara.

Untuk mengukur variabel pada penelitian ini, yaitu safety climate, perceived supervisor safety, psychological strain, dan safety performance, semu variabel tersebut diukur menggunakan skala Likert dengan lima skala jawaban dari 5 (sangat setuju) sampai dengan 1 (sangat tidak setuju). Untuk masing-masing variabel, safety climate diukur menggunakan 6 butir (Glendon \& Litherland, 2001), perceived supervisor safety menggunakan 5 butir (Zohar, 2000), psychological strain menggunakan 5 butir (Caplan, Cobb, French, Harrison, \& Pinneau, 1975), serta safety performance menggunakan 5 butir (Yusoff, Ariffin, Omar, \& Madero-Gomez, 2017). Pengujian validitas instrumen didasarkan pada evaluasi discriminant validity yang dilakukan dengan menyimpulkan hasil cross-loading pada setiap butir indikator pertanyaan masing-masing variabel. Sementara itu, pengujian reliabilitas didasarkan pada evaluasi composite reliability yang 
dapat disimpulkan memenuhi apabila nilainya lebih dari 0,7 dan memiliki Cronbach's alpha lebih besar dari 0,6 (Jogiyanto, 2011).

\section{HASIL DAN PEMBAHASAN}

\section{Diskripsi Responden}

Responden pada penelitian ini adalah karyawan Divisi Kapal Niaga PT PAL Indonesia (Persero), Surabaya yang berjumlah 115 orang termasuk karyawan aktif. Diskripsi responden pada penelitian ini meliputi profil jenis kelamin, usia, tingkat pendidikan terakhir, status pernikahan, dan masa kerja. Responden dalam penelitian mayoritas adalah laki-laki dengan proporsi $65 \%$, sedangkan perempuan sebesar $35 \%$. Sebagian besar responden berusia antara 20-30 tahun yaitu 41,7\%, usia 31-40 sebanyak 30,4\%, lebih dari 50 tahun sebanyak 21,7\%, dan usia 41-50 tahun sebanyak 8,6\%. Pada profil tingkat pendidikan terakhir, mayoritas responden lulusan sarjana (S1) sebanyak 47,8\%, kemudian Diploma 20,8\%, SMP 19,1\%, SMA/STM 9,3\%, dan SD 2,6\%. Sebagian besar responden telah menikah yaitu sebanyak $71,3 \%$, belum menikah $25,2 \%$, sedangkan duda/janda $3,4 \%$. Mayoritas responden telah memiliki masa kerja di perusahaan dalam rentang waktu 21-30 tahun sebanyak $63,3 \%$, sedangkan pada rentang masa kerja 11-20 tahun sebanyak $26,1 \%$, serta masa kerja 2-10 tahun sebanyak 10,4\%.

Tabel 2. Nilai Outer Loading dan AVE Model Struktural

\begin{tabular}{|c|c|c|}
\hline Indikator & Nilai Outer Loading & Average Variance Extracted (AVE) \\
\hline SCMV1 & 0,890 & \multirow{14}{*}{ 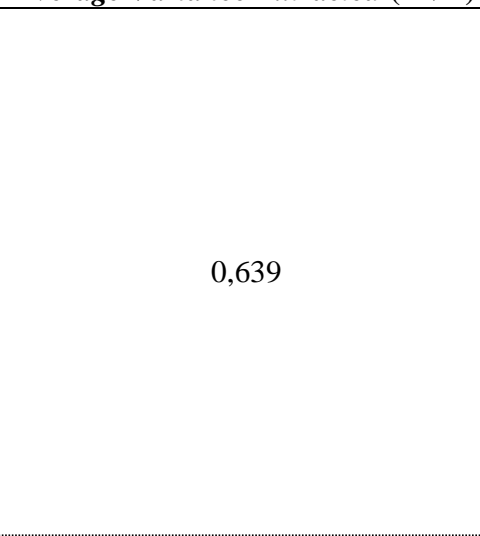 } \\
\hline SCMV2 & 0,906 & \\
\hline SCMV3 & 0,896 & \\
\hline SCSC1 & 0,875 & \\
\hline SCSC2 & 0,881 & \\
\hline SCSC3 & 0,862 & \\
\hline SCP1 & 0,918 & \\
\hline SCP2 & 0,929 & \\
\hline SCST1 & 0,880 & \\
\hline SCST2 & 0,917 & \\
\hline SCST3 & 0,916 & \\
\hline SCSE1 & 0,915 & \\
\hline SCSE2 & 0,899 & \\
\hline SCSE3 & 0,883 & \\
\hline PSS1 & 0,831 & \multirow{5}{*}{0,693} \\
\hline PSS2 & 0,819 & \\
\hline PSS3 & 0,814 & \\
\hline PSS4 & 0,834 & \\
\hline PSS5 & 0,863 & \\
\hline PS1 & 0,770 & \multirow{10}{*}{0,637} \\
\hline PS2 & 0,778 & \\
\hline PS3 & 0,805 & \\
\hline PS4 & 0,828 & \\
\hline PS5 & 0,812 & \\
\hline PS6 & 0,774 & \\
\hline PS7 & 0,819 & \\
\hline PS8 & 0,791 & \\
\hline PS9 & 0,848 & \\
\hline PS10 & 0,751 & \\
\hline SP1 & 0,886 & \multirow{5}{*}{0,790} \\
\hline SP2 & 0,925 & \\
\hline SP3 & 0,873 & \\
\hline SP4 & 0,909 & \\
\hline SP5 & 0,851 & \\
\hline
\end{tabular}




\section{Uji Validitas}

Evaluasi dilakukan terhadap instrumen penelitian ini untuk melakukan pengukuran measurement model pada variabel-variabel penelitian yang meliputi pengujian convergent validity, discriminant validity, dan composite reliability. Pengukuran convergent validity dievaluasi menggunakan nilai outer loading dengan batas ketentuan nilai outer loading lebih besar dari 0,5 sampai dengan 0,6 yang masih dianggap cukup. Selain nilai outer loading, evaluasi convergent validity dapat dilakukan dengan mengevaluasi nilai average variance extracted (AVE) yang harus lebih besar dari 0,50 (Hair, Matthews, Matthews, \& Sarstedt, 2011). Berdasarkan hasil olah data pada Tabel 2, nilai outer loading dari masing-masing indikator pertanyaan untuk semua variabel yang menyusun model struktural kesemuanya sudah memiliki nilai lebih besar dari 0,5 , sehingga dapat dikatakan bahwa indikator-indikator pertanyaan dalam model struktural telah memenuhi convergent validity. Evaluasi lainnya pada nilai average variance extracted pada masing-masing variabel semuanya juga telah memiliki nilai yang lebih besar dari 0,50 , yang juga menyimpulkan bahwa pengukuran variabel penelitian dalam model sudah memenuhi convergent validity. Setelah evaluasi convergent validity, analisis discriminant validity dilakukan menggunakan evaluasi Fornell-Larcker dan nilai cross-loading sebagai pengukurnya.

Menurut Hair et al. (2011), analisis Fornell-Larcker menunjukkan bahwa nilai akar AVE setiap variabel penelitian yang ditunjukkan pada baris diagonal (dicetak tebal) seharusnya memiliki nilai lebih besar daripada korelasi antarvariabel penelitian yang tertera di baris bukan diagonal (dicetak tidak tebal di Tabel 3). Berdasarkan data evaluasi pada Tabel 3 tersebut, maka evaluasi analisis Fornel-Larcker menyimpulkan bahwa discriminant validity model penelitian yang dianalisis dengan PLS ini telah terpenuhi.

Tabel 3. Evaluasi Fornell-Larcker

\begin{tabular}{lcccc}
\hline \multicolumn{1}{c}{ Variabel } & $\begin{array}{c}\text { Safety } \\
\text { Climate }\end{array}$ & $\begin{array}{c}\text { Perceived } \\
\text { Supervisor Safety }\end{array}$ & $\begin{array}{c}\text { Psychological } \\
\text { Strain }\end{array}$ & $\begin{array}{c}\text { Safety } \\
\text { Performance }\end{array}$ \\
\hline Safety Climate & $\mathbf{0 , 7 9 9}$ & & & \\
\hline $\begin{array}{l}\text { Perceived Supervisor } \\
\text { Safety }\end{array}$ & 0,417 & $\mathbf{0 , 8 3 2}$ & & \\
\hline $\begin{array}{l}\text { Psychological Strain } \\
\text { Safety Performance }\end{array}$ & $-0,587$ & $-0,559$ & $\mathbf{0 , 7 9 8}$ & \\
\hline Sumber & 0,589 & 0,541 & 0,787 & $\mathbf{0 , 8 8 9}$ \\
\hline
\end{tabular}

Sumber: Hasil olah data (2020).

\section{Uji Reliabilitas}

Evaluasi terakhir pada outer model adalah composite reliability yang menguji nilai reliabilitas pada masing-masing indikator dalam suatu variabel. Sebuah variabel dikatakan telah memenuhi composite reliability, apabila nilai composite reliability dan nilai Cronbach's alpha lebih besar dari 0,70 (Hair et al., 2011). Berikut ini merupakan nilai composite reliability pada masing-masing variabel. Berdasarkan hasil analisis pada Tabel 4, setiap variabel yang digunakan di dalam model penelitian memiliki nilai composite reliability dan nilai Cronbach's alpha lebih besar dari 0,7. Mengacu pada hasil 
evaluasi instrumen penelitian ini, maka masing-masing variabel dalam penelitian ini telah memenuhi composite reliability

Tabel 4. Nilai Composite Reliability dan Cronbach's Alpha

\begin{tabular}{lcc}
\hline \multicolumn{1}{c}{ Variabel } & Cronbach's Alpha & Composite Reliability \\
\hline Safety Climate & 0,956 & 0,961 \\
\hline Perceived Supervisor Safety & 0,889 & 0,919 \\
\hline Psychological Strain & 0,936 & 0,946 \\
\hline Safety Performance & 0,933 & 0,950 \\
\hline
\end{tabular}

Sumber: Hasil olah data (2020).

\section{Uji Koefisien Determinasi (R-square)}

Hasil uji statistik koefisien determinasi pada model penelitian ini menunjukkan nilai $\mathrm{R}^{2}$ (R-square) pada pengaruh variabel safety climate, perceived supervisor safety, dan psychological strain terhadap safety performance sebesar 0,655. Hasil tersebut menunjukkan bahwa persentase keragaman persepsi responden atas safety performance dalam bekerja di divisi kapal niaga PT PAL Indonesia (Persero) mampu dijelaskan oleh ketiga variabel lain yang digunakan dalam penelitian ini, yaitu safety climate, perceived supervisor safety, dan psychological strain sebesar 65,5\%, sedangkan sisanya sebesar $34,5 \%$ dijelaskan oleh variabel lain di luar model penelitian ini. Selanjutnya, nilai $\mathrm{R}^{2}$ pada pengaruh variabel antara safety climate dan perceived supervisor safety terhadap psychological strain diperoleh nilai $R$-square sebesar 0,464 yang dapat diartikan bahwa persentase keragaman persepsi responden atas psychological strain dalam bekerja di divisi kapal niaga PT PAL Indonesia (Persero) dapat dijelaskan oleh variabel safety climate dan perceived supervisor safety sebesar $46,4 \%$. Sementara itu, sisanya sebesar $53,6 \%$ dijelaskan oleh variabel lain di luar model penelitian ini.

\section{Uji Hipotesis}

Berdasarkan hasil uji t (t-statistics) yang ditunjukkan pada Tabel 5, nilai uji t pada pengaruh safety climate terhadap psychological strain sebesar 5,224 $(>1,64)$ dan nilai original sample sebesar - 0,428 (negatif), sehingga hasil tersebut dapat diartikan bahwa hipotesis kesatu (H1) terbukti kebenarannya. Artinya, apabila persepsi safety climate yang dirasakan karyawan semakin kecil, maka psychological strain akan semakin tinggi. Hasil penelitian ini didukung oleh penelitian Clarke (2006).

Hasil uji t terhadap hipotesis kedua (H2) menunjukkan bahwa nilai t pada pengaruh perceived supervisor safety terhadap psychological strain sebesar 5,475 (>1,64) dan original sample sebesar -0,380 (negatif). Hasil pengujian tersebut mengindikasikan bahwa $\mathrm{H} 2$ terbukti kebenarannya secara statistik. Artinya, apabila persepsi perceived supervisor safety yang dirasakan karyawan semakin baik, maka psychological strain cenderung semakin rendah. Hasil penelitian ini selaras dengan penelitian sebelumnya oleh Daud et al. (2015).

Hasil uji hipotesis ketiga (H3) menunjukkan bahwa nilai uji t pada pengaruh psychological strain terhadap safety performance sebesar $10,054(>1,64)$ dan nilai original sample sebesar -0,614 (negatif), sehingga H3 terbukti kebenarannya secara statstik. Artinya, apabila persepsi psychological strain yang dirasakan karyawan semakin tinggi, 
maka safety performance akan cenderung semakin rendah. Hasil penelitian ini senada dengan penelitian sebelumnya oleh Jex (1998).

Tabel 5. Hasil Pengujian Hipotesis

\begin{tabular}{lcccl}
\hline \multicolumn{1}{c}{$\begin{array}{c}\text { Pengaruh Antarvariabel } \\
\text { yang Diuji }\end{array}$} & Hipotesis & $\begin{array}{c}\text { t-statistics } \\
(>\mathbf{1 , 6 4})\end{array}$ & Original Sample & Keterangan \\
\hline $\begin{array}{l}\text { Safety Climate } \rightarrow \text { Psychological } \\
\text { Strain }\end{array}$ & $\mathrm{H} 1$ & 5,224 & $-0,428$ & $\begin{array}{l}\text { Signifikan, } \\
\text { Negatif }\end{array}$ \\
\hline $\begin{array}{l}\text { Perceived Supervisor Safety } \rightarrow \\
\text { Psychological Strain }\end{array}$ & $\mathrm{H} 2$ & 5,475 & $-0,380$ & $\begin{array}{l}\text { Signifikan, } \\
\text { Negatif }\end{array}$ \\
\hline $\begin{array}{l}\text { Psychological Strain } \rightarrow \text { Safety } \\
\text { Performance }\end{array}$ & $\mathrm{H} 3$ & 10,054 & $-0,614$ & $\begin{array}{l}\text { Signifikan, } \\
\text { Negatif }\end{array}$ \\
\hline $\begin{array}{l}\text { Safety Climate } \rightarrow \text { Psychological } \\
\text { Strain } \rightarrow \text { Safety Performance }\end{array}$ & $\mathrm{H} 4$ & 4,780 & 0,263 & $\begin{array}{l}\text { Signifikan, } \\
\text { Positif }\end{array}$ \\
$\begin{array}{l}\text { Supervisor Safety } \rightarrow \\
\text { Psychological Strain } \rightarrow \text { Safety }\end{array}$ & $\mathrm{H} 5$ & 4,855 & 0,234 & $\begin{array}{l}\text { Signifikan, } \\
\text { Performance }\end{array}$ \\
\hline Susitif
\end{tabular}

Sumber: Hasil olah data (2020).

Hasil uji hipotesis keempat (H4) menunjukkan bahwa nilai t pada pengaruh safety climate terhadap safety performance dengan mediasi psychological strain sebesar 4,780 $(>1,64)$ dan nilai original sample sebesar 0,263 (positif), sehingga H4 terbukti kebenarannya secara statstik. Artinya, pengaruh mediasi yang terjadi pada jalur pengaruh safety climate terhadap safety performance bersifat partial mediation, karena pengaruh langsung atau direct effect pada pengaruh safety climate terhadap safety performance juga dapat disimpulkan signifikan. Hasil penelitian ini mendukung penelitian sebelumnya oleh Siu et al. (2004).

Hasil uji hipotesis kelima (H5) menunjukkan bahwa uji t pada pengaruh perceived supervisor safety terhadap safety performance yang dimediasi oleh psychological strain sebesar 4,855 (>1,64) dan nilai original sample sebesar 0,234 (positif), sehingga H5 dapat dibuktikan kebenarannya secara statstik. Artinya, pengaruh mediasi yang terjadi pada jalur pengaruh perceived supervisor safety terhadap safety performance juga bersifat partial mediation, karena pengaruh langsung atau direct effect pada pengaruh perceived supervisor safety terhadap safety performance disimpulkan signifikan juga. Hasil penelitian ini selaras dengan penelitian sebelumnya oleh Khdair et al. (2011).

\section{Pembahasan}

Penelitian ini bertujuan untuk mengetahui pengaruh safety climate dan perceived supervisor safety terhadap safety performance, serta mediasi psychological strain pada karyawan yang bekerja di Divisi Kapal Niaga PT PAL Indonesia (Persero). Penelitian ini menemukan pengaruh signifikan safety climate dan perceived supervisor safety melalui mediasi psychological strain terhadap safety performance. Temuan pada penelitian ini membuktikan pengaruh signifikan dan negatif antara safety climate terhadap psychological strain. Hasil ini menunjukkan bahwa $\mathrm{H} 1$ terbukti kebenarannya. Hasil empiris di lapangan menunjukkan bahwa keadaan safety climate PT PAL Indonesia (Persero) dinilai cukup baik walaupun masih ada karyawan yang tidak peduli dengan iklim keselamatan yang ada di lingkungan kerja mereka. Temuan ini mendukung pernyataan 
Clarke (2006) bahwa apabila pekerja atau karyawan menerima beban kerja yang lebih berat, maka mereka akan mempunyai persepsi buruk atau negative safety climate.

Temuan berikutnya menunjukkan bahwa apabila perceived supervisor safety yang dirasakan karyawan semakin baik, maka psychological strain akan semakin rendah. Hasil ini melandasi temuan bahwa $\mathrm{H} 2$ dalam penelitian ini dapat diterima. Artinya, ketika pimpinan perusahaan telah memahami dan mempraktikkan prosedur keselamatan kerja, maka hal tersebut dapat menurunkan tingkat ketegangan psikologis pada karyawan. Temuan ini selaras dengan pemikiran Daud et al. (2015), yaitu suatu organisasi menciptakan permintaan dan harapan pada peran yang ada, sehingga organisasi akan mentrasfernya sebagai tekanan peran kepada individu dan bersifat berkelanjutan dalam menyelesaikan permasalahan kesehatan. Kondisi faktual di lapangan menunjukkan bahwa karyawan PT PAL Indonesia (Persero) telah diberikan edukasi dan pemahaman mengenai safety oleh para pimpinannya. Karyawan PT PAL Indonesia (Persero) telah melakukan kegiatan yang dinamakan TBM (Tool Box Meeting), yaitu sejenis apel pagi yang dilaksanakan setiap pagi sebelum melakukan pekerjaan secara rutin.

Hasil penelitian ini juga menemukan bahwa psychological strain berpengaruh signifikan dan berarah negatif terhadap safety performance. Dengan demikian, hasil ini menunjukkan bahwa H3 dapat diterima secara statistik. Pengaruh yang terjadi pada relasi ini memiliki arah negatif. Hasil uji tersebut menunjukkan bahwa apabila persepsi psychological strain yang dirasakan karyawan semakin tinggi, maka safety performance akan semakin rendah. Artinya, ketika karyawan merasakan tingginya tingkat ketegangan psikologis pada diri mereka, maka kondisi itu dapat mengakibatkan mereka menjadi lalai dalam hal keselamatan bekerjanya, sehingga tingkat safety performance akan menurun. Hasil penelitian ini sejalan dengan temuan Jex (1998) yang menyebutkan bahwa reaksi negated yang dihadapi karyawan terhadap stressor pekerjaan, salah satunya adalah ketegangan psikologis yang dapat berdampak pada safety performance perusahaan.

Temuan lain dari penelitian ini menunjukkan bahwa peran mediasi psychological strain pada pengaruh safety climate dan perceived supervisor safety terhadap safety performance diperoleh pengaruh tidak langsung, sehingga $\mathrm{H} 4$ dan $\mathrm{H} 5$ dapat diterima pula. Dalam hal ini, psychological strain dapat mempengaruhi tingkat safety performance, yaitu apabila seorang karyawan memiliki ketegangan psikologis yang sangat mengganggu kinerjanya, maka ia dapat membuat kesalahan yang berakibat tidak amannya kondisi tempat bekerjanya, serta membuatnya merasa terancam akan kondisi kesehatan dan keselamatan kerjanya. Kondisi lapangan menunjukkan bahwa karyawan PT PAL Indonesia (Persero) telah menerapkan iklim keselamatan yang cukup baik, karena banyak aturan tentang keselamatan yang mereka laksanakan. Namun, masih ada pula karyawan yang tidak dapat mengendalikan emosi, karena banyaknya tuntutan target pekerjaan yang diberikan oleh pemberi order untuk menyelesaikan project yang mereka berikan. Hasil penelitian ini mengarahkan pada perilaku kepemimpinan dan budaya keselamatan sebagai dua faktor penting yang mempengaruhi safety performance. Hal itu merujuk pada temuan Khdair et al. (2011) yang menyatakan bahwa hubungan antara pemimpin dan safety performance di dalam perusahaan sangat penting, karena faktorfaktor tersebut akan berpengaruh terhadap performa perusahaan.

\section{KESIMPULAN DAN SARAN}

Hasil penelitian ini menunjukkan bahwa safety climate berpengaruh signifikan dan negatif terhadap psychological strain. Temuan tersebut dapat diartikan bahwa keti- 
ka karyawan merasakan iklim keselamatan di dalam perusahaan tidak begitu kuat atau rendah, maka kondisi itu akan meningkatkan stres atau ketegangan psikologis pada karyawan. Tekanan psikologis dapat membahayakan karyawan ketika ia melakukan suatu pekerjaan. Selanjutnya, perceived supervisor safety ditemukan memiliki pengaruh signifikan dan negatif terhadap psychological strain. Hasil tersebut diartikan bahwa ketika pimpinan perusahaan telah memahami dan mempraktikkan prosedur keselamatan kerja di dalam perusahaan, maka hal itu dapat menurunkan tingkat ketegangan psikologis pada karyawan. Pemahaman terhadap praktik keselamatan oleh pimpinan dapat membantu karyawan untuk mendapatkan solusi tentang penerapan prosedur keselamatan dengan baik. Penelitian ini juga menemukan bahwa psychological strain berpengaruh signifikan dan negatif terhadap safety performance. Ketika karyawan merasakan tingkat ketegangan psikologis yang tinggi, maka mereka dapat bertindak lalai dalam melaksanakan prosedur keselamatan kerja, sehingga tingkat safety performance dapat menurun.

Di sisi lain, variabel safety climate dan perceived supervisor safety berpengaruh signifikan dan positif terhadap safety performance. Hasil ini mengindikasikan bahwa ketika safety climate dan perceived supervisor safety rendah, maka safety performance perusahaan cenderung pada titik yang rendah pula, sedangkan tingkat psychological strain yang tinggi dapat berdampak signifikan dan negatif pada safety performance perusahaan. Hal tersebut dikarenakan karyawan yang mempunyai psychological strain yang tinggi, maka mereka cenderung semakin lalai dalam menaati aturan dan prosedur Keselamatan dan Kesehatan Kerja (K3) dan akan berdampak pada safety performance perusahaan. Implikasi hasil penelitian ini bagi manajemen adalah upaya untuk menyediakan media komunikasi dan fasilitas bagi pekerja dan pihak manajemen. Komunikasi yang terjalin dengan baik dapat meningkatkan hubungan yang baik antarpihak tersebut. Penelitian selanjutnya disarankan untuk merancang disain penelitian yang lebih menyeluruh mulai dari awal proyek hingga tahap akhir untuk mendapatkan persepsi safety climate yang lebih baik.

\section{DAFTAR REFERENSI}

Arikunto, S. (2002). Prosedur Penelitian: Suatu Pendekatan Praktik. Jakarta: PT Rineka Cipta.

Caplan, R. D., Cobb, S., French, J. R. P. Jr., Harrison, R. U. \& Pinneau, S. R. Jr. (1975). Job Demands and Worker Health, U.S. Department of Health, Education, and Welfare Publication No. 75-160. U.S. Government Printing Office. Washington D.C.: The Institute for Social Research.

Clarke, S. (2006). The Relationship between Safety Climate and Safety Performance: A Meta-analytic Review. Journal of Occupational Health Psychology, 11(4), 315327.

Cooper, M. D., \& Phillips, R. A. (2004). Exploratory Analysis of the Safety Climate and Safety Behavior Relationship. Journal of Safety Research, 35(5), 497-512. https://doi.org/10.1016/j.jsr.2004.08.004.

Daud, N., Yaakob, Y., \& Ghazali, S. N. M. (2015). Quality of Work Life and Organizational Commitment: Empirical Investigation among Academic in Public Institution of Higher Learning. International Journal of Applied Business and Economic Research, 13(7), 6129-6146. 
Dessler, G. (2015). Human Resources Management (Manajemen Sumber Daya Manusia). Ed. 14. Edisi Bahasa Indonesia. Penerj. Paramita Rahayu. Jakarta: Indeks.

Dov, Z. (2008). Safety Climate and Beyond: A Multi-level Multi-climate Framework. Safety Science, 46(3), 376-387.

Flin, R., Mearns, K., O’Connor, P., \& Bryden, R. (2000). Measuring Safety Climate: Identifying the Common Features. Safety Science, 34(1-3), 177-192.

Ghozali, I. (2011). Aplikasi Analisis Multivariate dengan Program SPSS. Cetakan IV. Semarang; Badan Penerbit Universitas Diponegoro.

Glendon, A. I., \& Litherland, D. K. (2001). Safety Climate Factors, Group Differences and Safety Behaviour in Road Construction. Safety Science, 39(3), 157-188. https://doi.org/10.1016/S0925-7535(01)00006-6.

Hagan, P. E., Montgomery, J. F., \& O'Reilly, J. T. (2001). Accident Prevention Manual for Business and Industry. 12th edition. Illinois, USA: NSC.

Hair, Jr., J. F., Matthews, L. M., Matthews, R. L., \& Sarstedt, M. (2017). PLS-SEM or CB-SEM: updated guidelines on which method to use. International Journal of Multivariate Data Analysis, 1(2), 107-123. https://doi.org/10.1504/ijmda.2017. 087624.

Hasibuan, C. F., \& Lubis, N. R. (2018). Evaluasi Penerapan Safety Climate Menggunakan NOSAQ-50 di Perusahaan Perkebunan PT. XYZ. Elkawnie: Journal of Islamic Science and Technology, 4(2), 115-126.

Hersey, P., Blanchard, K. H., \& Dewey, E. J. (2008). Management of Organizational Behavior: Leading Human Resources. 8th Eds. Upper Saddle River, NJ: Pearson Prentice-Hall.

Hofmann, D. A., Morgeson, F. P., \& Gerras, S. J. (2003). Climate as a Moderator of the Relationship between LMX and Content-specific Citizenship Behavior: Safety Climate as an Exemplar. Journal of Applied Psychology, 88(1), 170-178. DOI:10.1037/0021-9010.88.1.170.

Hofmann, D. A., \& Stetzer, A. (1996). A Cross-level Investigation of Factors Influencing Unsafe Behaviors and Accidents. Personnel Psychology, 49(2), 307339.

ISafetyMagazine.com (2017). Kecelakaan Kerja Konstruksi 2017 Diprediksi Tetap Tinggi. Safety at Work, 1 Februari. Diakses tanggal 15 Juni 2020 di https://isafetymagazine.com/kecelakaan-kerja-konstruksi-2017-diprediksi-tetaptinggi.

Jex, S. M. (1998). Stress and Job Performance: Theory, Research, and Implications for Managerial Practice. Thousand Oaks, California: Sage Publications, Ltd.

Jex, S. M., Beehr, T. A., \& Roberts, C. K. (1992). The Meaning of Occupational Stress Items to Survey Respondents. Journal of Applied Psychology, 77(5), 623-628. https://doi.org/10.1037/0021-9010.77.5.623.

Jogiyanto, H. M. (2011). Metodologi Penelitian Bisnis. Edisi Keempat. Yogyakarta: BPFE.

Kahn, R. L., Wolfe, D. M., Quinn, R. P., Snoek, J. D., \& Rosenthal, R. A. (1964). Organizational Stress: Studies in Role Conflict and Ambiguity. New York: John Wiley. 
Khdair, W. A., Shamsudin, F. M., \& Subramanim, C. (2011). Improving Safety Performance by Understanding Relationship between Management Practices and Leadership Behavior in the Oil and Gas Industry in Iraq: A Proposed Model. 2011 International Conference on Management and Artificial Intelligence, Bali, Indonesia, IPEDR Vol 6, 85-93.

Lu, C. -S., \& Yang, C. -S. (2011). Safety Climate and Safety Behavior in the Passenger Ferry Context. Accident Analysis \& Prevention, 43(1), 329-341. https://doi.org/10.1016/j.aap.2010.09.001.

Mohr, G., Müller, A., Rigotti, T., Aycan, Z., \& Tschan, F. (2006). The Assessment of Psychological Strain in Work Contexts: Concerning the Structural Equivalency of Nine Language Adaptations of the Irritation Scale. European Journal of Psychological Assessment, 22(3), 198-206. https://doi.org/10.1027/10155759.22.3.198.

Neal, A., Griffin, M. A., \& Hart, P. M. (2000). The Impact of Organizational Climate on Safety Climate and Individual Behavior. Safety Science, 34(1-3), 99-109.

PT PAL Indonesia (Persero) (2020). Laporan Keselamatan dan Kesehatan Kerja PT PAL Indonesia (Persero) Tahun 2016-2018. Surabaya, Indonesia.

Robbins, S. P., (2001). Organizational Behavior: Concepts, Controversies, and Applications. Ninth edition. Englewood Cliffs, New Jersey: Prentice-Hall.

Silvia, S., Ihsan, T., \& Rizky, I. A. (2020). Analisis Iklim Keselamatan Kerja dan Pengaruh Karakteristik Responden pada Bagian Produksi di PT. X. Jurnal Serambi Engineering, 5(3), 1155-1164.

Singer, S., Lin, S., Falwell, A., Gaba, D., \& Baker, L. (2009). Relationship of Safety Climate and Safety Performance in Hospitals. Health Services Research, 44(2), 399-421. https://doi.org/10.1111/j.1475-6773.2008.00918.x.

Siu, O. -L., Phillips, D. R., \& Leung, T. -W. (2004). Safety Climate and Safety Performance among Construction Workers in Hong Kong: The Role of Psychological Strains as Mediators. Accident Analysis \& Prevention, 36(3), 359366. https://doi.org/10.1016/S0001-4575(03)00016-2.

Skeepers, N. C., \& Mbohwa, C. (2015). A Study on the Leadership Behaviour, Safety Leadership, and Safety Performance in the Construction Industry in South Africa. Procedia Manufacturing, 4, 10-16. https://doi.org/10.1016/j.promfg.2015.11.008.

Spector, P. E., \& Jex, S. M. (1998). Development of Four Self-report Measures of Job Stressors and Strain: Interpersonal Conflict at Work Scale, Organizational Constraints Scale, Quantitative Workload Inventory, and Physical Symptoms Inventory. Journal of Occupational Health Psychology, 3(4), 356367. https://doi.org/10.1037/1076-8998.3.4.356.

Spector, P. E., \& O'Connell, B. J. (1994). The Contribution of Personality Traits, Negative Affectivity, Locus of Control and Type A to the Subsequent Reports of Job Stressors and Job Strains. Journal of Occupational and Organizational Psychology, 67(1), 1-12. https://doi.org/10.1111/j.2044-8325.1994.tb00545.x.

Spielberger, C. D., \& Reheiser, E. C. (1994). The Job Stress Survey: Measuring Gender Differences in Occupational Stress. Journal of Social Behavior and Personality, 9(2), 199-218. 
Stacciarini, J. -M. R., \& Tróccoli, B. T. (2004). Occupational Stress and Constructive Thinking: Health and Job Satisfaction. Journal of Advanced Nursing, 46(5), 480487. https://doi.org/10.1111/j.1365-2648.2004.03022.x.

Sugiyono, S. (2017). Metode Penelitian Kuantitatif Kualitatif dan $R \& D$. Bandung: Alfabeta.

Sultana, S., Andersen, B. S., \& Haugen, S. (2019). Identifying Safety Indicators for Safety Performance Measurement Using a System Engineering Approach. Process Safety and Environmental Protection, 128, 107-120.

Sell, M. V., Brief, A. P., \& Schuler, R. S. (1981). Role Conflict and Role Ambiguity: Integration of the Literature and Directions for Future Research. Human Relations, 34(1), 43-71. https://doi.org/10.1177/001872678103400104.

Wilson, M. G., Dejoy, D. M., Vandenberg, R. J., Richardson, H. A., \& McGrath, A. L. (2004). Work Characteristics and Employee Health and Well-being: Test of a Model of Healthy Work Organization. Journal of Occupational and Organizational Psychology, 77(4), 565-588.

Xu, J., Lian, L. -J., Wu, C., Wang, X. -F., Fu, W. -Y., \& Xu, L. -H. (2008). Lead Induces Oxidative Stress, DNA Damage and Alteration of p53, Bax and Bcl-2 Expressions in Mice. Food and Chemical Toxicology, 46(5), 1488-1494. https://doi.org/10.1016/j.fct.2007.12.016.

Yusoff, Y. M., Ariffin, S. K., Omar, K., \& Madero-Gomez, S. M. (2017). Safety Performance in the Workplace: A Proposed Model for Understanding the Influencing Factors on Safety Climate. Advanced Science Letters, 23(11), 10660 10663(4).

Zohar, D. (2000). A Group-level Model of Safety Climate: Testing the Effect of Group Climate on Microaccidents in Manufacturing Jobs. Journal of Applied Psychology, 85(4), 587-596. https://doi.org/10.1037/0021-9010.85.4.587. 